\title{
In vitro cytotoxic, antifungal, trypanocidal and leishmanicidal activities of acetogenins isolated from Annona cornifolia A. St. -Hil. (Annonaceae)
}

\author{
LUCIANA A.R.S. LIMA ${ }^{1}$, TÂNIA M.A. ALVES ${ }^{2}$, CARLOS L. ZANI ${ }^{2}$, POLICARPO A. SALES JÚNIOR ${ }^{2}$, \\ ALVARO J. ROMANHA ${ }^{2}$, SUSANA JOHANN ${ }^{3}$, PATRÍCIA S. CISALPINO ${ }^{3}$, LÚCIA P.S. PIMENTA ${ }^{4}$ \\ and MARIA AMÉLIA D. BOAVENTURA ${ }^{4}$ \\ ${ }^{1}$ Universidade Federal de São João Del Rei, Campus Centro-Oeste Dona Lindu, \\ Rua Sebastião Gonçalves Coelho, 400, Chanadour, 35501-296 Divinópolis, MG, Brasil \\ ${ }^{2}$ Centro de Pesquisas René Rachou/FIOCRUZ, Avenida Augusto Lima, 1715, \\ Barro Preto, 30190-002 Belo Horizonte, MG, Brasil \\ ${ }^{3}$ Departamento de Microbiologia, Instituto de Ciências Biológicas, Universidade Federal de Minas Gerais, \\ Avenida Antônio Carlos, 6627, Pampulha, 31270-901 Belo Horizonte, MG, Brasil \\ ${ }^{4}$ Departamento de Química, Instituto de Ciências Exatas, Universidade Federal de Minas Gerais, \\ Avenida Antônio Carlos, 6627, Pampulha, 31270-901 Belo Horizonte, MG, Brasil \\ Manuscript received on February 8, 2013; accepted for publication on November 11, 2013
}

\begin{abstract}
Annona cornifolia A. St. -Hil. is a small annual perennial tree found in the Brazilian savannah; their green fruit is popularly used in the treatment of ulcers. The acetogenins isolated from the seeds of Annona cornifolia previously showed to possess antioxidant activity. In continuation of our investigations on the biological activities of acetogenins, four binary mixtures and ten pure adjacent bis-tetrahydrofuran annonaceous acetogenins were evaluated: the cytotoxic (against three human tumor cell lines), antifungal (against Paracoccidioides brasiliensis), trypanocidal (against Trypanosoma cruzi) and leishmanicidal (against Leishmania amazonensis) activities. Acetogenins presented cytotoxic activity confirming their potential use in anti-cancer therapy. Regarding leishmanicidal and trypanocidal activities, an inhibition of $87 \%$ of $L$. amazonensis amastigotes and $100 \%$ of $T$. cruzi amastigotes and trypomastigotes was observed, when tested at the concentration of $20 \mu \mathrm{g} \mathrm{mL}^{-1}$. Moreover, six acetogenins showed more activity against all the three tested isolates of $P$. brasiliensis than trimethoprim-sulfamethoxazole, a drug used for treating paracoccidioidomycosis. Thus, acetogenins may be an alternative in treating a number of diseases that have a huge impact on millions of people worldwide. This paper reports for the first time the antifungal, leishmanicidal and trypanocidal activities for these acetogenins.
\end{abstract}

Key words: Annona cornifolia, acetogenins, cytotoxic, antifungal, trypanocidal, leishmanicidal.

\section{INTRODUCTION}

Several Annona species of the Annonaceae family produce edible fruits that are widely consumed in Brazil, such as Annona squamosa and Annona muricata. Annona cornifolia A. St. -Hil., with orange fruits, is a small annual perennial tree

Correspondence to: Luciana Alves Rodrigues dos Santos Lima E-mail: luarsantos@ufsj.edu.br found in the Brazilian savannah; their green fruit is popularly used in the treatment of ulcers (Correa 1984). Annonaceous acetogenins, isolated exclusively from the Annonaceae family until 2008 (Pettit et al. 2008), exhibit a broad range of biological properties (Yang et al. 2009). Our group has already investigated acetogenins from the seeds of A. crassiflora (Santos et al. 1994, 1996) and A. 
cornifolia (Santos et al. 2006, 2007, Lima et al. 2009, 2010), as well as from the leaves of Rollinia laurifolia (Pimenta et al. 2001, 2003, 2005). There are no reports on the study of other parts of Annona cornifolia, including the phytochemical studies of the fruit. The fruits of several Annona species are an important source of proteins, carbohydrates and amino acids (Correa 1984). Further research may shed light on the use of fruit of $A$. cornifolia in future dietary supplementation.

Leishmaniasis and trypanosomiasis, occurring in tropical and sub-tropical areas around the world, have huge medical, social and economic impact to millions of people (Castillo-Garit et al. 2012). Paracoccidioidomycosis, a systemic disorder caused by the dimorphic fungus, Paracoccidioides brasiliensis, occurs in Latin American countries, resulting in more deaths than leishmaniasis in Brazil (Shikanai-Yasuda et al. 2006). In the absence of drug therapy, paracoccidioidomycosis is usually fatal (Shikanai-Yasuda et al. 2006, Johann et al. 2010). In the treatment of cancer, chemotherapeutic agents exhibit severe toxicity and can cause many undesirable side effects. Therefore, it is necessary to find new drugs, with natural products being good candidates. In fact, from 1983 to 1994, more than $60 \%$ of approved anticancer drugs were derived from natural products (Newman et al. 2003).

In the present study, we evaluated the cytotoxic, antifungal, trypanocidal and leishmanicidal activities of fifteen adjacent bis-tetrahydrofuran (THF) acetogenins: ten pure (3-8 and 11-14) and four binary mixtures $(\mathbf{1}+\mathbf{2}, \mathbf{8}+\mathbf{9}, \mathbf{8}+\mathbf{1 0}$ and $\mathbf{8 + 1 5})$, isolated from the ethanol extracts of seeds from $A$. cornifolia A. St. -Hil. (Fig. 1).

\section{MATERIALS AND METHODS}

GENERAL

Etoposide, amphotericin B, sulforhodamine B, tris[hydroxymethyl]aminomethane buffer, trichloracetic acid, RPMI medium, methyl thiazolyl tetrazolium and Schneider's medium were purchased from Sigma-Aldrich (St. Louis, USA). Benznidazole was obtained from Roche (São Paulo, Brazil), and trimethoprim/sulfamethoxazole from Ducto (Goiás, Brazil). Trypsin-EDTA, RPMI 1640 medium without phenol red and gentamicin were purchased from Gibco (NY, USA). Silica gel 230-400 mesh from Merck (Darmstadt, Germany) was used for column chromatography, and silica gel Merck 60G was used for thin-layer chromatography. All solvents used were of PA and HPLC grade and purchased from Vetec (Brazil) and Sigma, respectively.

The 1D and 2D NMR spectra of acetogenins were performed on Brucker Avance DRX 400 spectrometers (Ettlingen, Germany) in $\mathrm{CDCl}_{3}$, containing $0.1 \%$ tetramethylsilane as the internal chemical shift standard. Electrospray Ionization Mass Spectrometry (ESI-MS) was performed using a Waters MICROMAS Q-TOF (Milford, Massachusetts, USA) equipped with an electrospray ion (ESI) source. A $200 \mu \mathrm{g} \mathrm{mL} \mathrm{m}^{-1}$ solution of acetogenins in $\mathrm{MeCN}-\mathrm{H}_{2} \mathrm{O}$ (1:1) was infused at $2 \mathrm{~mL} \mathrm{~min}^{-1}$, and the positive mass spectra was acquired with a $\mathrm{m} / \mathrm{z}$ range between 50 and 1,000 daltons. The cone voltages were optimized for positive ion analysis in the range between 35 and $50 \mathrm{~V}$. In the MS/MS experiments, the parent ion isolation width was 3.8 daltons, and the normalized collision energy was set at 30\% for the compounds. Fifty scans were collected from 50 to 700 daltons to generate an average spectrum. Optical rotation was measured on a Perkin Elmer 341 polarimeter (Waltham, Massachusetts, USA). Final purification was performed on a Waters 501 apparatus (Milford, Massachusetts, USA) with a 486 UV-detector and a 746 integrator.

\section{Plant MATERIAL}

The fruits of Annona cornifolia A. St. -Hil. were collected from the Curvelo, Minas Gerais, Brazil, from January to March 1998. The species were identified by Dr. R. Mello-Silva and a voucher specimen (BHCB 68114) was deposited at the 
Instituto de Ciências Biológicas Herbarium, with $\mathrm{C}_{6} \mathrm{H}_{14}$ and $\mathrm{CHCl}_{3}$, resulting in 79.5, 7.3 Universidade Federal de Minas Gerais, Belo Horizonte, MG, Brazil.

EXTRACTION AND ISOLATION

Extraction of the dried and powdered seeds (850.0 g), by percolation (EtOH, $7 \mathrm{~L}, 50 \mathrm{~h}$ ) gave a brown residue (120.0 g, F01), that was dissolved in $\mathrm{MeOH} / \mathrm{H}_{2} \mathrm{O}$ (3:7) and successively extracted and $21.1 \mathrm{~g}$ of hexane (F02), chloroform (F03) and hydroalcoholic (F04) fractions, respectively. Extract and fractions were evaporated to dryness before column chromatography and HPLC.

Acetogenins 3-7 and mixture $\mathbf{1}+\mathbf{2}$ were isolated from F02, and acetogenins 8-15 from F03. The isolation of acetogenins 1-7 and 11-14 are described in previous publications by our group (Santos et

a)

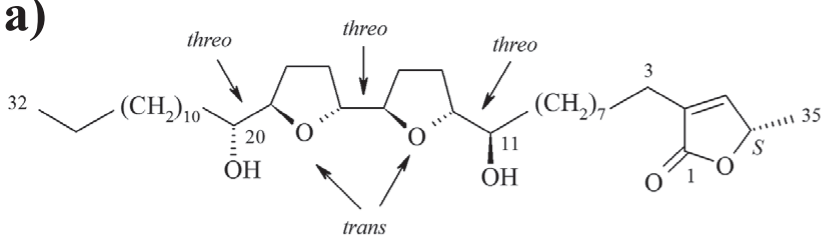

4-Desoxylongimicin B (1)

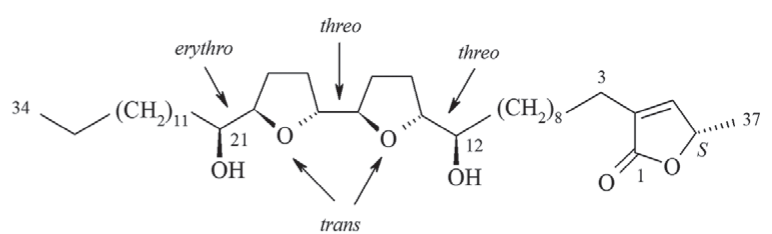

Folianin A (2)

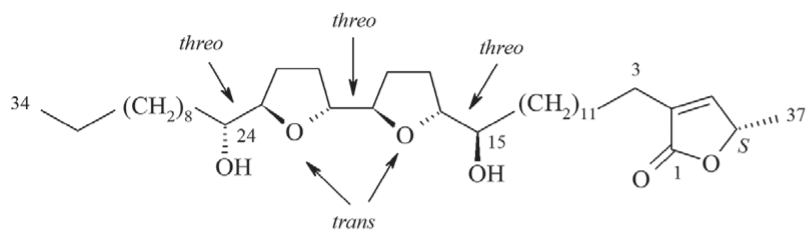

Squamocin M or Isodesacetyluvaricin (3)

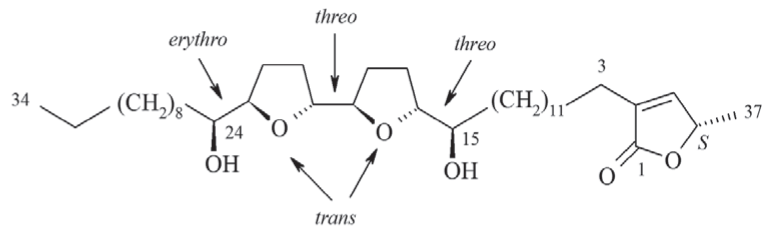

Squamocin L or Desacetyluvaricin (4)

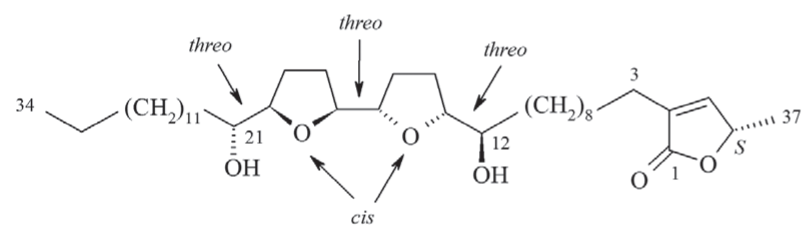

Folianin B (5)

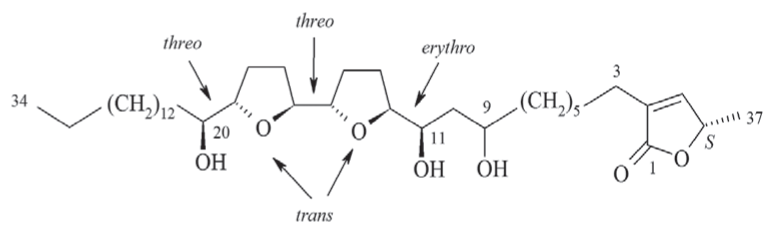

Annofolin (6)

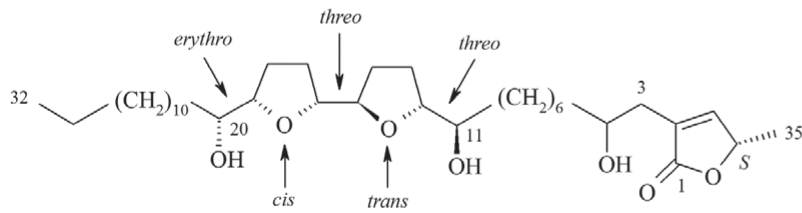

Isolongimicin B (7)

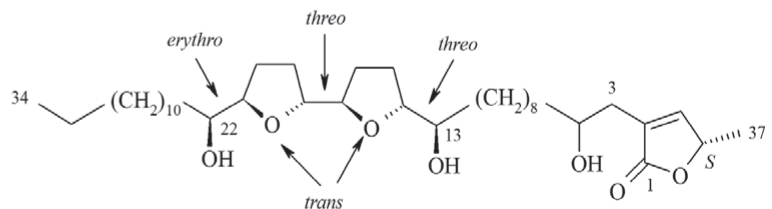

Glaucanisin (8)

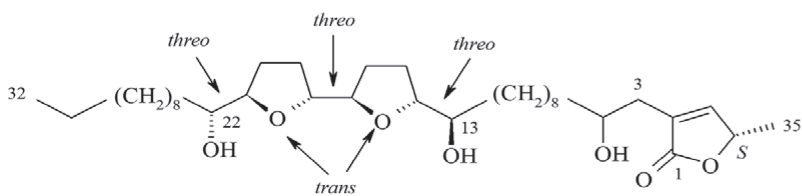

Parviflorin or Squamocin E (9)

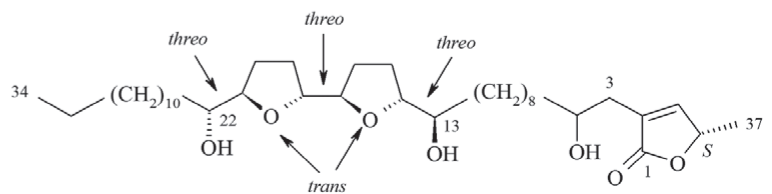

Glaucanetin (10)

Figure 1 - Acetogenins isolated from Annona cornifolia. A) Acetogenins 1-10, B) Acetogenins 11-15. 


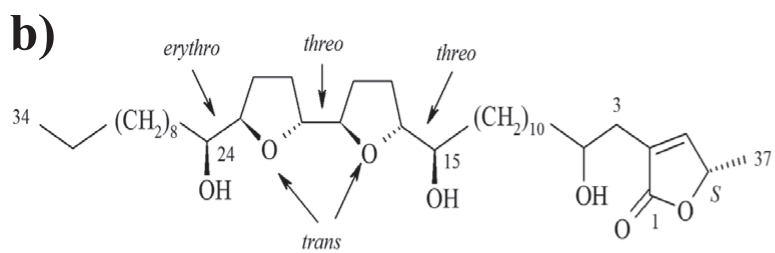

Bullatacin or Rolliniastatin-2 (11)

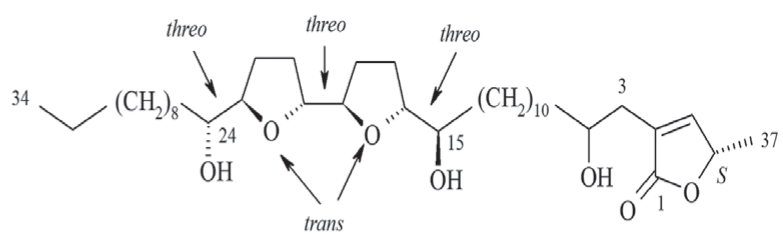

Asimicin or Squamocin H (12)

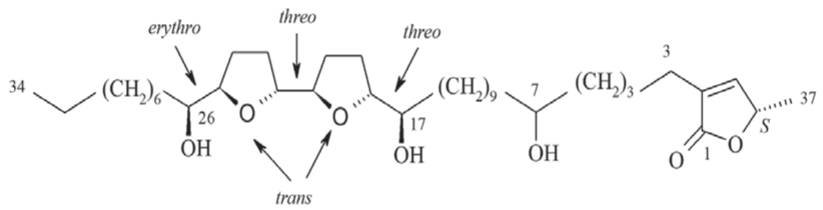

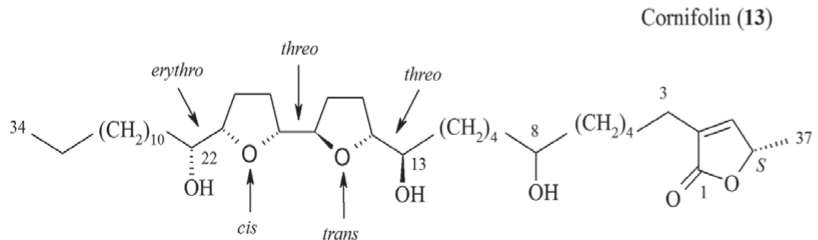

Annotacin (14)

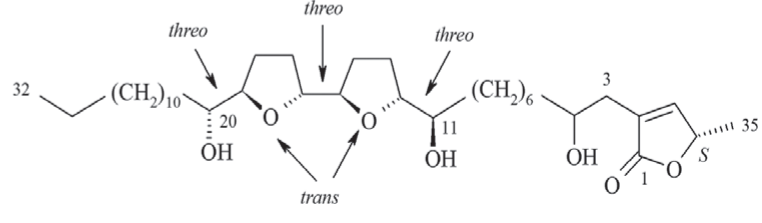

Longimicin B (15)

Figure 1 (continuation) - Acetogenins isolated from Annona cornifolia. A) Acetogenins 1-10, B) Acetogenins 11-15.

al. 2006, Lima et al. 2009, 2010). F02 was chromatographed leading to $15.1 \mathrm{mg}$ of a mixture of acetogenins 4-desoxylongimicin B + folianin A (1+2), $38.7 \mathrm{mg}$ of squamocin $\mathrm{M}$ or isodesacetyluvaricin (3), $38.0 \mathrm{mg}$ of squamocin L or desacetyluvaricin (4), $14.7 \mathrm{mg}$ of folianin B (5), $40.0 \mathrm{mg}$ of annofolin (6), and $6.0 \mathrm{mg}$ of isolongimicin B (7). The acetogenins bullatacin or rolliniastatin-2 (11) $(10.5 \mathrm{mg})$, asimicin or squamocin $\mathrm{H}$ (12) (3.5 mg), cornifolin (13) (30.4 mg), and annotacin (14) (12.0 mg) were obtained from F03. The isolation of acetogenins 8-10 and 15 are described below. Chloroform fraction $(\mathrm{F} 03,2.0 \mathrm{~g})$ was fractionated by normal phase MPLC (with $\mathrm{C}_{6} \mathrm{H}_{14} / \Phi \mathrm{CH}_{3} / \mathrm{EtOAc} / \mathrm{MeOH}$ pure or in mixtures of increasing polarity), yielding 54 fractions of $75 \mathrm{~mL}$ each, combined according to their TLC patterns, yielding 10 groups of fractions. G-7 (620.0 mg, positive to Kedde reagent) underwent column chromatography $(1.5 \times 25 \mathrm{~cm}$, $50.0 \mathrm{~g} \mathrm{SiO}_{2}$ 230-400 mesh, $\mathrm{CH}_{2} \mathrm{Cl}_{2} / \mathrm{MeOH}$ 97:3), yielding 52 fractions of $15 \mathrm{~mL}$ each, combined according to their TLC patterns in 19 subgroups of fractions. Subgroup 2 (45.4 mg) was submitted to a RP-HPLC (Shim-pack C18 $5.0 \mu \mathrm{m}, 20$ x $250 \mathrm{~mm}$ cartridge column, flow rate $15 \mathrm{~mL} \mathrm{~min}^{-1}, \mathrm{MeCN} / \mathrm{H}_{2} \mathrm{O}$ 70:30, detection $220 \mathrm{~nm}$ ), leading to glaucanisin (8) $(6.0 \mathrm{mg})$, to glaucanisin + parviflorin $(\mathbf{8}+\mathbf{9})$ $(14.0 \mathrm{mg})$ and to glaucanisin + glaucanetin $(\mathbf{8}+\mathbf{1 0})$ (14.9 mg). Subgroup 7 (90.1 mg), from G-7, led to 15 subfractions, after being submitted to purification by RP-HPLC (Supelco SPLC-18 $5.0 \mu \mathrm{m}, 10 \times 250 \mathrm{~mm}$ cartridge column, flow rate $2.5 \mathrm{~mL} \mathrm{~min}^{-1}, \mathrm{MeCN} / \mathrm{H}_{2} \mathrm{O}$ 60:40, detection $220 \mathrm{~nm}$ ). Subgroup 11 (84.7 mg), from G-7, by HPLC (same conditions as above) gave mixture of glaucanisin + longimicin B $(\mathbf{8}+\mathbf{1 5})(14.0 \mathrm{mg})$.

\section{CYтотоXic Assay}

The cytotoxic potential of acetogenins against the human melanoma (UACC-62), renal carcinoma (TK-10) and breast cancer (MCF-7) cell lines was evaluated in November 2001, using the sulforhodamine B (SRB) assay adopted by the National Cancer Institute, USA (Monks et al. 1991). All cells were cultured in RPMI medium supplemented with $5 \% \mathrm{FBS}$ and gentamicin, at $37^{\circ} \mathrm{C}$ 
with $5 \% \mathrm{CO}_{2}$. Shortly before reaching confluence, the cells were detached with trypsin-EDTA and seeded into 96-well plates so that $100 \mu \mathrm{L}$ in each well contained 10,000 UACC-62 and MCF-7 cells or 15,000 TK-10 cells. Acetogenins dissolved in DMSO $1 \%$ were tested firstly in triplicate at $20 \mu \mathrm{g} \mathrm{mL}^{-1}$, and after at different concentrations, acetogenins that inhibits $75 \%$ of growth human tumor cell lines. After 48 hours in the presence of the compound, the cells were fixed by adding $50 \mu \mathrm{L}$ of cold $50 \%(\mathrm{w} / \mathrm{v})$ trichloracetic acid to each well and incubating the plate at $4^{\circ} \mathrm{C}$ for $1 \mathrm{~h}$. The supernatant was then discarded and the cells were washed five times with water. After drying at room temperature, $50 \mu \mathrm{L}$ of SRB solution $(0.4 \% \mathrm{w} / \mathrm{v}$ in $1 \%$ acetic acid $)$ was added to each well, and the plate incubated for $30 \mathrm{~min}$ at $4^{\circ} \mathrm{C}$. Unbound SRB was removed by washing five times with $1 \%$ acetic acid and the plates were dried at room temperature overnight. The plates were read at $515 \mathrm{~nm}$ after dissolution of the dye with Tris buffer (tris[hydroxymethyl] aminomethane). Etoposide was used as the positive control and $0.2 \%$ DMSO as the negative control. Each experiment was performed in triplicate. The concentration of the compound that produces 50\% of growth inhibition ( $\mathrm{IC}_{50}$, cytostatic effect) and the concentration of the compound that kills $50 \%$ of cells $\left(\mathrm{LD}_{50}\right.$, cytocidal effect) were obtained from data of three independent experiments by nonlinear regression using SOFTmax pro 5.3.

\section{ANTIFUNGAL ACTIVITY}

Antifungal activity was evaluated in February 2004 and repeated in March 2011, with similar results. In vitro antifungal activity against Paracoccidioides brasiliensis, strains $\mathrm{Pb}-01$ (ATCC- MYA-826), $\mathrm{Pb}-18$ and $\mathrm{Pb}-18$ virulent isolates (from the fungal collection of the Faculty of Medicine of the Universidade de São Paulo, SP, Brazil) were prepared in accordance with the guidelines in the CLSI document M27-A3 (CLSI 2008) and modified according to the suggestions of Johann et al. (2010), to obtain a final suitable inoculum dilution for each strain. After homogenization by vortexing, the transmittance of the suspension was measured at wavelengths of $530 \mathrm{~nm}$ and adjusted to 69 to $70 \%$.

The Minimal Inhibitory Concentration (MIC) was obtained from broth microdilution testing performed in accordance to described methods (CLSI 2008, Johann et al. 2010). Amphotericin B and trimethoprim-sulfamethoxazole were included as positive antifungal control. Their stock solutions were prepared in DMSO and water, respectively.

The Minimal Fungicidal Concentration (MFC) values for acetogenins were determined as follows: from the microtiter plate used to determine the MIC values, the test wells that showed: a) complete fungal growth inhibition (clear wells), b) growth similar to that of the no-drug control well, and c) growth control wells, were selected for the assay to determine the MFC. The MFC was determined as the lowest drug concentration at which fewer than three colonies were able to grow (Espinel-Ingroff et al. 2001).

\section{TRYPANOCIDAL ACTIVITY}

In vitro assay with amastigote and trypomastigote forms of Trypanosoma cruzi was performed in October 2003 and repeated in June 2013, with similar results, according to protocols established by Buckner et al. (1996) with modifications (Romanha et al. 2010). Briefly, parasites and culture procedures: T. cruzi (Tulahuen strain) expressing the Escherichia coli $\beta$-galactosidase gene were grown on monolayer of mouse L929 fibroblasts. Cultures to be assayed for $\beta$-galactosidase activity were grown in RPMI 1640 medium (pH 7.27.4) without phenol red plus $10 \%$ foetal bovine serum and glutamine. For the bioassay, 96 well tissue culture microplates were seeded with $L 929$ fibroblasts in $80 \mu \mathrm{L}$ with a density of $4.0 \times 10^{3}$ fibroblasts per well and incubated overnight at $37^{\circ} \mathrm{C}$ and $5 \% \mathrm{CO}_{2} . \beta$-galactosidase-expressing 
trypomastigotes in $20 \mu \mathrm{L}$ of medium were then added at a density of $4.0 \times 10^{4}$ per well. After $2 \mathrm{~h}$ of contact, the medium with trypomastigotes that had not penetrated the cells was discarded and replaced by $200 \mu \mathrm{L}$ of fresh medium. After $48 \mathrm{~h}$, the medium was discarded again and replaced by $180 \mu \mathrm{L}$ of fresh medium and $20 \mu \mathrm{L}$ of a solution of acetogenins at concentration of $20 \mu \mathrm{g} \mathrm{mL}{ }^{-1}$. Each compound was tested in triplicate. After seven days of culture development, chlorophenol red $\beta$-Dgalactopyranoside at $100 \mu \mathrm{M}$ and Nonidet P-40 at $0.1 \%$ were added to the plates and the plates were then incubated overnight at $37^{\circ} \mathrm{C}$. The absorbance was measured at $570 \mathrm{~nm}$ in an automated microplate reader. Benznidazole at its half maximal inhibitory concentration $\left(\mathrm{IC}_{50}\right)(1 \mu \mathrm{g} / \mathrm{mL}=3.8 \mu \mathrm{M})$ was used as a positive control. The results were expressed as the percentage of parasite growth inhibition.

Cytotoxic test for determination of the Selectivity Index (SI) was performed in June 2013. In vitro cytotoxic test was also carried out to determine the toxicity of the compounds over L929 cells by alamarBlue ${ }^{\circledR}$. The same cell number, time of the cells development and time of compound exposure were used for the $\beta$-galactosidase assay. After 96 hours of compounds exposure the alamarBlue ${ }^{\circledR}$ was added and the absorbance at 570 and $600 \mathrm{~nm}$ was measured after 4-6 h. The cell viability was expressed as the percentage of difference in the reduction between treated and untreated cells (Romanha et al. 2010). IC I0 $_{50}$ values were calculated by linear interpolation and the Selectivity Index (SI) was determined based on the ratio of the $\mathrm{IC}_{50}$ value in the host cell divided by the $\mathrm{IC}_{50}$ value of the parasite $\left(\mathrm{IC}_{50} / \mathrm{IC}_{50}\right.$ ratio).

\section{LEISHMANICIDAL ACTIVITY}

Assays with amastigote-like forms of Leishmania (Leishmania) amazonensis were performed in September 2003, using the MTT (methyl thiazolyl tetrazolium)-based colorimetric assay (Callahan et al. 1997). Amphotericin B was used as the positive control. Promastigotes forms of L. amazonensis (strain IFLA/BR/196/PH-8) were obtained from lesions of experimentally infected hamsters. The parasites were incubated for 9 days at $26^{\circ} \mathrm{C}$ in Schneider's medium, buffered at $\mathrm{pH}$ 7.2. The promastigotes forms were then stimulated to differentiate into amastigote-like forms by rising the incubation temperature to $32^{\circ} \mathrm{C}$ and lowering the $\mathrm{pH}$ of the medium to 6.0. After 7 days under these conditions, $90 \%$ of the parasites differentiated. The parasite concentration was adjusted to $1 \times 10^{8}$ cells $\mathrm{mL}^{-1}$, and $90 \mu \mathrm{L}$ were added to each well of 96-well plates, followed by $10 \mu \mathrm{L}$ of the solutions containing the samples $\left(20 \mu \mathrm{g} \mathrm{mL}^{-1}\right)$ and control drug $(0.2 \mu \mathrm{g}$ $\mathrm{mL}^{-1}$ amphotericin B). Only compounds that caused at least $75 \%$ of inhibition were tested again in different concentration. The plates were incubated at $32^{\circ} \mathrm{C}$ for $72 \mathrm{~h}$ and the number of parasites was estimated using the MTT based colorimetric assay. The $\mathrm{LD}_{50}$ (lethal dose that kills $50 \%$ of cells) was obtained from data of three independent experiments by non-linear regression using the SOFTmax pro 5.3.

\section{STATISTICAL ANALYSES}

Measurements were conducted in triplicate. All the data are shown as mean standard deviation (SD). The values of $p<0.05$ were considered statistically significant.

\section{RESULTS AND DISCUSSION}

The identification (by IR, ${ }^{1} \mathrm{H}$ and ${ }^{13} \mathrm{C}$ NMR and MS spectra) of acetogenins 1-2, 5-7, and 13-14, isolated for the first time from Annona cornifolia, are described in previous publications by our group (Santos et al. 2006, Lima et al. 2009, 2010). Spectrometric data of the known acetogenins (new for this specie) 3-4 and 11-12 are described by Lima et al. (2010). The acetogenins squamocin L (4) and squamocin M (3) were isolated by Sahai et al. (1994). The squamocin L was identical with desacetyluvaricin, isolated from Uvaria accuminata as well as Annona glabra seeds. The squamocin M 
was identical with isodesacetyluvaricin, isolated from Uvaria narum (Sahai et al. 1994, Zeng et al. 1996, Cavé et al. 1997). Acetogenins 8-10 and 15 were compared to other molecules in the literature: glaucanisin (8) (Waechter et al. 1995), parviflorin or squamocin E (9) (Gallardo et al. 1998), glaucanetin (10) (Waechter et al. 1997) and longimicin B (15) (Ye et al. 1996).

The cytotoxic activities of acetogenins 1-15 at $20 \mu \mathrm{g} \mathrm{mL} \mathrm{L}^{-1}$ are shown in Table I. $\mathrm{IC}_{50}$ and $\mathrm{LD}_{50}$ were established only for those that inhibited $75 \%$ of the cells at the concentration of $20 \mu \mathrm{g} \mathrm{mL}^{-1}$ (Table II). These acetogenins exhibited significant cytotoxic activity and selectivity for the tumor cell lines, being more active against MCF-7. Annofolin (6) presented lower $\mathrm{LD}_{50}$ values than the etoposide for all the lines tested, while annofolin (6), isolongimicin $\mathrm{B}(\mathbf{7})$ and the mixtures $\mathbf{8}+\mathbf{9}, \mathbf{8}+\mathbf{1 0}$ and $\mathbf{8}+\mathbf{1 5}$ showed lower $\mathrm{IC}_{50}$ values than the etoposide for the TK-10 cell line. The mixtures showed higher cytostatic activity than pure glaucanisin (8) against TK-10 and UACC-62 cells, suggesting a potentiation of the effect by the two acetogenins.
Yang et al. (2009) established that (i) adjacent bis-THF acetogenins are the most potent antitumor agents among this class of compounds, (ii) if all other structural features are identical, C-35 acetogenins are more active than those with 37 carbon atoms; (iii) for better activity, the distance between the $\mathrm{OH}$-flanked THF and the $\gamma$-lactone must be 13 carbon atoms, and (iv) acetogenins with stereochemical arrangement of threo/trans/threo/ trans/threo around THF rings are less potent than those with stereochemical arrangement of threo/ trans/threo/trans/erythro. However, annofolin (6), the most active agent in this work, is interestingly a C-37 acetogenin with 9 carbon atoms between the OH-flanked THF and the $\gamma$-lactone, presenting a stereochemical arrangement of erythro/trans/threo/ trans/threo around THF rings.

The ten pure and the four mixtures of acetogenins were tested against three isolates of Paracoccidioides brasiliensis ( $\mathrm{Pb} 01, \mathrm{~Pb} 18$ and $\mathrm{Pb} 18$ virulent) at $1.17-150 \mu \mathrm{g} \mathrm{mL} \mathrm{m}^{-1}$, their Minimal Inhibitory Concentration (MIC) and Minimal Fungicidal Concentration (MFC) being determined.

TABLE I

In vitro effect of acetogenins from Annona cornifolia, tested at $20 \mu \mathrm{g} \mathrm{mL} \mathrm{L}^{-1}$, against human cancer cell lines, Trypanosoma cruzi and Leishmania amazonensis.

\begin{tabular}{|c|c|c|c|c|c|}
\hline Acetogenins & MCF-7 (\%) & TK $10(\%)$ & UACC $62(\%)$ & T. cruzi $(\%)$ & L. amazonensis (\%) \\
\hline $1+2$ & $93.0 \pm 11.3^{*}$ & $77.5 \pm 24.7^{*}$ & $75.5 \pm 12.0^{*}$ & $76.2 \pm 5.1^{*}$ & $58.5 \pm 3.0^{*}$ \\
\hline 3 & $116.0 \pm 2.0^{*}$ & $85.5 \pm 12.0$ & $40.5 \pm 0.7^{*}$ & $64.1 \pm 6.5^{*}$ & $41.7 \pm 1.1^{*}$ \\
\hline 4 & $66.3 \pm 5.8^{*}$ & $38.5 \pm 4.7^{*}$ & $36.5 \pm 0.7^{*}$ & $40.7 \pm 6.2^{*}$ & $35.3 \pm 2.5^{*}$ \\
\hline 5 & $69.3 \pm 8.5^{*}$ & $44.5 \pm 3.5^{*}$ & $39.0 \pm 2.8^{*}$ & $23.4 \pm 1.0^{*}$ & $56.7 \pm 6.2^{*}$ \\
\hline 6 & $103.0 \pm 13.8$ & $91.0 \pm 9.9^{*}$ & $81.0 \pm 8.5^{*}$ & $97.6 \pm 3.4^{*}$ & $87.0 \pm 0.0^{*}$ \\
\hline 7 & $109.6 \pm 11.0^{*}$ & $81.5 \pm 6.3$ & $77.5 \pm 3.5^{*}$ & $36.8 \pm 2.2^{*}$ & $57.5 \pm 4.1^{*}$ \\
\hline 8 & $109.0 \pm 0.5^{*}$ & $75.6 \pm 2.1^{*}$ & $75.0 \pm 5.4^{*}$ & $17.1 \pm 2.0^{*}$ & $34.8 \pm 5.4^{*}$ \\
\hline 11 & $50.0 \pm 1.0^{*}$ & $21.0 \pm 1.4^{*}$ & $28.0 \pm 1.4^{*}$ & $24.5 \pm 1.0^{*}$ & $55.3 \pm 7.2^{*}$ \\
\hline 12 & $53.3 \pm 4.7^{*}$ & $19.5 \pm 2.1^{*}$ & $32.0 \pm 1.4^{*}$ & $20.7 \pm 3.4^{*}$ & $55.5 \pm 6.3^{*}$ \\
\hline 13 & $30.0 \pm 5.3^{*}$ & $17.0 \pm 0.8^{*}$ & $19.0 \pm 0.7^{*}$ & $2.0 \pm 0^{*}$ & $55.6 \pm 5.0^{*}$ \\
\hline 14 & $103.3 \pm 3.5$ & $75.5 \pm 7.1^{*}$ & $75.1 \pm 1.4^{*}$ & $51.9 \pm 5.5^{*}$ & $76.9 \pm 5.1^{*}$ \\
\hline $8+9$ & $105.0 \pm 12.1$ & $91.2 \pm 13.3^{*}$ & $76.5 \pm 1.4^{*}$ & $77.2 \pm 10.2^{*}$ & $49.6 \pm 2.3^{*}$ \\
\hline $8+10$ & $107.0 \pm 5.2$ & $79.3 \pm 4.8^{*}$ & $80.5 \pm 1.8^{*}$ & $100.0 \pm 5.1^{*}$ & $46.2 \pm 1.0^{*}$ \\
\hline $8+15$ & $108.0 \pm 10.4$ & $88.0 \pm 2.9^{*}$ & $80.0 \pm 1.4^{*}$ & $38.6 \pm 5.4^{*}$ & 0.0 \\
\hline Etoposide $^{\mathrm{a}}$ & $105.0 \pm 16.4$ & $83.5 \pm 2.0$ & $88.0 \pm 2.8$ & - & - \\
\hline Amphotericin $\mathbf{B}^{\mathrm{a}}$ & - & - & - & - & $79.0 \pm 1.0$ \\
\hline Benznidazole ${ }^{\mathrm{a}}$ & - & - & - & $73.0 \pm 0.0$ & - \\
\hline
\end{tabular}

${ }^{\text {a}}$ Positive control: Etoposide was tested at $8 \mu \mathrm{g} \mathrm{mL} L^{-1}$, amphotericin B at $0.2 \mu \mathrm{g} \mathrm{mL}^{-1}$, and benznidazole at $1 \mu \mathrm{g} \mathrm{mL}{ }^{-1}$. Each value in the table is the mean \pm standard deviation $(n=3)$.

$* \mathrm{p}<0.05$ compared with positive control. 
TABLE II

In vitro cytotoxicity, trypanocidal and leishmanicidal activities of acetogenins from Annona cornifolia.

\begin{tabular}{|c|c|c|c|c|c|c|c|c|c|}
\hline \multirow{3}{*}{ Acetogenins } & \multicolumn{6}{|c|}{ Cytotoxic activity $(\mu \mathbf{M})$} & \multicolumn{2}{|c|}{ T. cruzi } & \multirow{3}{*}{$\begin{array}{c}\text { L. amazonensis } \\
\mathbf{L D}_{50}{ }^{b} \\
(\mu \mathrm{M})\end{array}$} \\
\hline & \multicolumn{2}{|c|}{ MCF-7 } & \multicolumn{2}{|c|}{ TK-10 } & \multicolumn{2}{|c|}{ UACC-62 } & \multirow{2}{*}{$\begin{array}{l}\mathbf{I C}_{\mathbf{5 0}}^{\mathrm{a}} \\
(\mu \mathbf{M})\end{array}$} & \multirow{2}{*}{$\mathbf{S I}^{\mathrm{c}}$} & \\
\hline & $\mathrm{IC}_{\mathbf{5 0}}^{\mathrm{a}}$ & $\mathbf{L D}_{\mathbf{5 0}}{ }^{\mathbf{b}}$ & $\mathrm{IC}_{50}^{\mathrm{a}}$ & $\mathbf{L D}_{50}{ }^{b}$ & $\mathrm{IC}_{\mathbf{5 0}}^{\mathrm{a}}$ & $\mathbf{L D}_{50}{ }^{b}$ & & & \\
\hline $1+2$ & $5.9^{*}$ & $>1.7 \times 10^{2}$ & $5.7 \times 10^{1^{*}}$ & $1.9 \times 10^{2 *}$ & $9.2 \times 10^{1 *}$ & $>1.7 \times 10^{2}$ & $1.2 \times 10^{-1^{*}}$ & 1 & - \\
\hline 3 & $<3.1 \times 10^{-1}$ & $>1.6 \times 10^{2}$ & $4.1 \times 10^{1^{*}}$ & $>1.6 \times 10^{2}$ & nt & nt & $1.0 \times 10^{-1 *}$ & 1 & - \\
\hline 6 & $<3.0 \times 10^{-1}$ & $7.8 \times 10^{1 *}$ & $6.4^{*}$ & $1.4 \times 10^{2 *}$ & $1.5 \times 10^{1 *}$ & $1.1 \times 10^{2 *}$ & $1.1 \times 10^{-1 *}$ & 1 & $6.4 \times 10^{1}$ \\
\hline 7 & $<3.2 \times 10^{-1}$ & $2.1 \times 10^{2 *}$ & $1.7 \times 10^{1^{*}}$ & $2.1 \times 10^{2 *}$ & $2.9 \times 10^{1 *}$ & $>1.7 \times 10^{2}$ & - & - & - \\
\hline 8 & $<3.0 \times 10^{-1}$ & $>1.6 \times 10^{2}$ & $9.5 \times 10^{1 *}$ & $>1.6 \times 10^{2}$ & $1.7 \times 10^{2 *}$ & 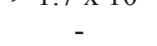 & - & - & - \\
\hline 14 & $<3.0 \times 10^{-1}$ & $2.1 \times 10^{2 *}$ & $9.5 \times 10^{1 *}$ & $>1.6 \times 10^{2}$ & $1.5 \times 10^{2 *}$ & - & 1.7 & 1 & $7.2 \times 10^{1}$ \\
\hline $8+9$ & $<3.2 \times 10^{-1}$ & $>1.7 \times 10^{2}$ & $5.3^{*}$ & $>1.7 \times 10^{2}$ & $3.5 \times 10^{1 *}$ & $>1.7 \times 10^{2}$ & $1.3 \times 10^{-1^{*}}$ & 1 & - \\
\hline $8+10$ & $<3.0 \times 10^{-1}$ & $>1.6 \times 10^{2}$ & $2.1 \times 10^{1^{*}}$ & $>1.6 \times 10^{2}$ & $2.2 \times 10^{1 *}$ & $2.0 \times 10^{2 *}$ & 1.7 & 1 & - \\
\hline $8+15$ & $<3.2 \times 10^{-1}$ & $>1.7 \times 10^{2}$ & $9.6^{*}$ & $1.7 \times 10^{2}$ & $2.3 \times 10^{1 *}$ & $>1.7 \times 10^{2}$ & - & - & - \\
\hline Etoposide $^{\mathrm{d}}$ & $<3.2 \times 10^{-1}$ & $>1.7 \times 10^{2}$ & $3.4 \times 10^{1}$ & $>1.7 \times 10^{2}$ & 5.3 & $>1.7 \times 10^{2}$ & - & - & - \\
\hline Benznidazole $^{\mathrm{d}}$ & - & - & - & - & - & - & 3.8 & 625 & - \\
\hline
\end{tabular}

${ }^{a}$ concentration that inhibits $50 \%$ of growth (cytostatic effect); ${ }^{b}$ concentration that kills $50 \%$ of the cells or parasites (cytocidal effect); ${ }^{\mathrm{c}}$ Selectivity Index (SI) is the ratio of $\mathrm{IC}_{50}$ on normal cell line to the $\mathrm{IC}_{50}$ on parasite; ${ }^{\mathrm{d}}$ positive control.

nt: not tested

${ }^{*} \mathrm{p}<0.05$ compared with positive control.

MIC and MFC values were found to be equal and are presented in Table III. Acetogenins 5-12 showed antifungal activity at concentrations $\leq 150$ $\mu \mathrm{g} \mathrm{mL}^{-1}$, thus being more active than trimethoprimsulfamethoxazole, the first class of drugs used to treat paracoccidioidomycosis, but less active than amphotericin B. Cornifolin (13) was inactive at this concentration against all three isolates. Annofolin (6), isolongimicin B (7) and bullatacin (11) showed the highest levels of activity against the three isolates of $P$. brasiliensis. $\mathrm{Pb} 18$ exhibited some selectivity, being more sensitive to squamocin $M$ (3) and folianin B (5).

There are few studies in the literature reporting the activity of natural products against the pathogenic fungus $P$. brasiliensis. The natural product $(R)$ goniothalamin and its synthetic enantiomer were evaluated against a panel of microorganisms that included three strains of $P$. brasiliensis $(\mathrm{Pb}-01$, $\mathrm{Pb}-18$ and $\mathrm{Pb}-\mathrm{B} 339)$. Their MIC values were in the range between 7 and $22 \mu \mathrm{g} \mathrm{mL}^{-1}$ for $P$. brasiliensis (Fátima et al. 2008). In this study, annofolin (6) and isolongimicin B (7) showed higher activity than the goniothalamin enantiomers against $P$. brasiliensis. In the experiment carried out by Lima et al. (2011), the authors tested the in vitro susceptibility of twelve clinical $P$. brasiliensis isolates to 9-hydroxy-folianin, an adjacent bisTHF acetogenin. The results demonstrated that all isolates were susceptible to 9-hydroxy-folianin, with a MIC of 3.4 to $27.7 \mu \mathrm{g} \mathrm{mL}^{-1}$. In our study, annofolin (6) was more active than 9-hydroxyfolianin against the three isolates of $P$. brasiliensis.

The acetogenins, at $20 \mu \mathrm{g} \mathrm{mL}^{-1}$, were also tested against the amastigote and trypomastigote forms of T. cruzi. The results are expressed in percentages of parasite growth inhibition (Table I). Squamocin M (3), annofolin (6), annotacin (14) and the mixtures $(\mathbf{1}+\mathbf{2}),(\mathbf{8}+\mathbf{9})$ and $(\mathbf{8}+\mathbf{1 0})$ inhibited more than 50\% of amastigote and trypomastigote forms of T. cruzi; their $\mathrm{IC}_{50}$ values are given in Table II.

All the acetogenins showed similar or greater trypanocidal effects as compared to benznidazole ( $\mathrm{IC}_{50}$ values less $1.7 \mu \mathrm{M}$ ), but showed toxicity at the same concentration, causing $50 \%$ of cell death (L929 cells). Thereby, no selective toxicity 
TABLE III

In vitro antifungal activity of acetogenins from Annona cornifolia against Paracoccidioides brasiliensis.

\begin{tabular}{|c|c|c|c|}
\hline \multirow{2}{*}{ Acetogenins } & \multicolumn{3}{|c|}{ MIC and MFC $\left(\mu \mathrm{g} \mathrm{mL}^{-1}\right)^{\mathrm{a}}$} \\
\hline & $\mathrm{Pb} 01$ & $\mathrm{~Pb} 18$ & $\mathrm{~Pb} 18$ virulent \\
\hline $1+2$ & nd & nd & nd \\
\hline 3 & $>150.0$ & $75.0^{*}$ & $>150.0$ \\
\hline 4 & $150.0^{*}$ & $150.0^{*}$ & $>150.0$ \\
\hline 5 & $150.0^{*}$ & $75.0^{*}$ & $150.0^{*}$ \\
\hline 6 & $9.3^{*}$ & $9.3^{*}$ & $9.3^{*}$ \\
\hline 7 & $18.7^{*}$ & $18.7^{*}$ & $18.7^{*}$ \\
\hline 8 & $150.0^{*}$ & $75.0^{*}$ & $75.0^{*}$ \\
\hline 11 & $37.5^{*}$ & $37.5^{*}$ & $37.5^{*}$ \\
\hline 12 & $150.0^{*}$ & $150.0^{*}$ & $150.0^{*}$ \\
\hline 13 & $>150.0$ & $>150.0$ & $>150.0$ \\
\hline 14 & $150.0^{*}$ & $>150.0$ & $>150.0$ \\
\hline $8+9$ & nd & nd & nd \\
\hline $8+10$ & nd & nd & nd \\
\hline $8+15$ & nd & nd & nd \\
\hline Amphotericin $\mathrm{B}^{\mathbf{b}}$ & 0.12 & 0.062 & 0.062 \\
\hline Trimethoprim-sulfamethoxazole ${ }^{\mathbf{b}}$ & 300 & 300 & 300 \\
\hline
\end{tabular}

${ }^{a}$ MIC: Minimal Inhibition Concentration; MFC: Minimal Fungicidal Concentration; ${ }^{b}$ positive control. nd: no detected activity at $150.0 \mu \mathrm{g} \mathrm{mL}$.

$* \mathrm{p}<0.05$ compared with positive control.

to the parasites was observed (Selectivity Index, SI $=1$ ) when a tissue culture assay was used. The acetogenins 3, 6, 14 and the mixtures $(\mathbf{1}+\mathbf{2})$, $(\mathbf{8}+\mathbf{9})$ and $(\mathbf{8}+\mathbf{1 0})$ showed growth inhibition of the parasites in the range of $51.9-100.0 \%$ (Table I). This level of activity is considered to be significant (Croft et al. 1988). Some studies confirmed the trypanocidal activity of the acetogenins against $T$. cruzi parasites (Waechter et al. 1998, GonzálezColoma et al. 2002).

The activity of all acetogenins against $L$. amazonensis amastigotes was evaluated (also at $20 \mu \mathrm{g} \mathrm{mL}^{-1}$ ). Those that presented inhibition higher than $75 \%$ had their $\mathrm{LD}_{50}$ values determined (Table II). Annofolin (6) and annotacin (14), both C-37 bisTHF acetogenins, were the most active, presenting LD values of $6.4 \times 10^{1}$ and $7.2 \times 10^{1} \mu \mathrm{M}$, respectively, indicating the relevance of these compounds in the search for new leishmanicidal drugs.

Few works report the leishmanicidal activity of acetogenins with one or two THF rings against the promastigote and amastigote forms of Leishmania (Waechter et al. 1998, RaynaudLe Grandic et al. 2004, Vila-Nova et al. 2011). According to Raynaud-Le Grandic et al. (2004), the stereostructural arrangement of threo/trans/ threo/trans/erythro around the THF ring favors leishmanicidal activity. Annofolin (6), with the stereostructural arrangement erythro/trans/ threo/trans/threo, exerted the highest level of leishmanicidal activity among the acetogenins tested in this work.

\section{CONCLUSIONS}

Although the cytotoxic activity of acetogenins has already been described, the high level of this activity observed in these compounds confirms their potential for being used in anti-cancer therapy. Regarding leishmanicidal and trypanocidal activities, an inhibition of $87 \%$ of $L$. amazonensis amastigotes and $100 \%$ of $T$. cruzi amastigotes and trypomastigotes was observed, when tested at the concentration of $20 \mu \mathrm{g} \mathrm{mL} \mathrm{m}^{-1}$. Moreover, six acetogenins showed more activity against all the three tested isolates of 
P. brasiliensis than trimethoprim-sulfamethoxazole, a drug used for treating paracoccidioidomycosis. Thus, acetogenins hold great promise in treating a number of diseases that have a huge impact on millions of people worldwide.

\section{ACKNOWLEDGMENTS}

We are grateful to Dr. Renato Mello-Silva for the botanical identification of this plant species.

\section{RESUMO}

Annona cornifolia A. St. -Hil. é uma pequena árvore anual perene encontrada no cerrado brasileiro; seu fruto verde é usado popularmente no tratamento de úlceras. As acetogeninas isoladas a partir das sementes de Annona cornifolia anteriormente apresentaram atividade antioxidante. Continuando as nossas investigações sobre as atividades biológicas das acetogeninas, quatro misturas binárias e dez acetogeninas bis-tetrahidrofurânicas adjacentes puras foram avaliadas quanto às atividades: citotóxica (sobre três linhagens de células tumorais humanas), antifúngica (sobre Paracoccidioides brasiliensis), tripanocida (sobre Trypanosoma cruzi) e leishmanicida (sobre Leishmania amazonensis). As acetogeninas apresentaram atividade citotóxica, confirmando seu uso potencial na terapia anticâncer. Quanto às atividades leishmanicida e tripanocida, foi observada uma inibição de $87 \%$ das formas amastigotas de L. amazonensis e $100 \%$ de formas amastigotas e tripomastigotas de $T$. cruzi, quando testadas a uma concentração de $20 \mu \mathrm{g} \mathrm{mL}^{-1}$. Além disso, seis acetogeninas mostraram maior atividade sobre todas as três cepas testadas de $P$. brasiliensis que o trimetoprim-sulfametoxazol, um medicamento usado no tratamento da paracoccidioidomicose. Assim, as acetogeninas podem ser uma alternativa no tratamento de uma série de doenças que têm um enorme impacto em milhões de pessoas no mundo. Este trabalho relata pela primeira as atividades antifúngica, leishmanicida e tripanocida para estas acetogeninas.

Palavras-chave: Annona cornifolia, acetogeninas, citotóxica, antifúngica, tripanocida, leishmanicida.

\section{REFERENCES}

BUCKNER FS, VERLINDE CL, LA FLAMME AC AND VAN VOORHIS WC. 1996. Efficient technique for screening drugs for activity against Trypanosoma cruzi using parasites expressing $\beta$-galactosidase. Antimicrob Agents Chemother 40: 2592-2597.

Callahan HL, Portal aC, Devereaux R and Grogl M. 1997. An axenic amastigote system for drug screening. Antimicrob Agents Chemother 41: 818-822.

Castillo-Garit JA, ABAD C, Rodrígues-Borges JE, MARRERO-PONCE Y AND TORRENS F. 2012. A review of QSAR studies to discover new drug-like compounds against leishmaniasis and trypanosomiasis. Curr Top Med Chem 12: 852-865.

Cavé A, Figadère B, Laurens A and Cortes D. 1997. Acetogenins from annonaceae. In: CAVÉ A, CORTES D, FIGADÈRE B, LAURENS AAND PETTIT GR. Progress in the chemistry of organic natural products, New York: Springer-Wien, p. 81-289.

CLSI - ClinICAL AND LABORATORY STANDARDS INSTITUTE. 2008. Reference method for broth dilution antifungal susceptibility testing of yeasts: approved standard - Third Ed. CLSI document M27-A3. CLSI, Wayne, PA, USA.

Correa MP. 1984. Dicionário de plantas úteis do Brasil e de plantas exóticas cultivadas, Rio de Janeiro: Imprensa Nacional 1: 194.

Croft SL, WALKER JJ AND GuTTERIDGE WE. 1988. Screening of drugs for rapid activity against Trypanosoma cruzi trypomastigotes in vitro. Trop Med Parasitol 39: 145-148.

ESPINEL-INGROFF A, BOYLE K AND SHEEHAN DJ. 2001. In vitro antifungal activities of voriconazole and reference agents as determined by NCCLS methods: review of the literature. Mycopathologia 150: 101-115.

FÁtima A, Martins CVB, De Resende MA, Ferreira Magalhães TF, SANTIAGo Lima BH, Watanabe GA, Gois RuIZ ALT, DE CARVALHo JE AND PILli RA. 2008 Antifungal activity of goniothalamin enantiomers. Lett Drug Des Discov 5: 74-78.

Gallardo T, ARAgon R, TORMO JR, BlazQuez MA, ZAFraPOLO MC AND CORTES D. 1998. Acetogenins from Annona glabra seeds. Phytochemistry 47: 811-816.

GonzÁlez-Coloma A, GuAdaÑo A, De InÉs C, MARTíneZDíAZ R AND CORTES D. 2002. Selective action of acetogenin mitochondrial complex I inhibitors. Z Naturforsch C 57: 1028-1034.

Johann S, Cisalpino PS, Watanabe GA, Cota BB, De Siqueira EP, Pizzolatti MG, ZANi CL ANd DE REsEnde MA. 2010. Antifungal activity of extracts of some plants used in the Brazilian traditional medicine against the pathogenic fungus Paracoccidioides brasiliensis. Pharm Biol 48: 388-396.

LIMA LARS, JOHANN S, CISALPINO PS, PIMENTA LPS AND BOAVENTURA MAD. 2011. Antifungal activity of 9-hydroxy-folianin and sucrose octaacetate from the seeds of Annona cornifolia A. St. -Hil. (Annonaceae). Food Res Int 44: 2283-2288. 
LIMA LARS, PIMENTA LPS AND BOAVENTURA MAD. 2009. Two new adjacent bis-tetrahydrofuran annonaceous acetogenins from seeds of Annona cornifolia. Planta Med 75: 80-83

LIMA LARS, PIMENTA LPS AND BoAVENTURA MAD. 2010. Acetogenins from Annona cornifolia and their antioxidant capacity. Food Chem 122: 1129-1138.

Monks A, Scudiero D, Skehan P, Shoemaker R, Paull K, Vistica D, Hose C, LANGley J, CROnise P AND VAigroWOLFF A. 1991. Feasibility of a high-flux anticancer drug screen using a diverse panel of cultured human tumor cell lines. J Natl Cancer Inst 83: 757-766.

Newman DJ, Cragg GM And Snader KM. 2003. Natural products as sources of new drugs over the period 19812002. J Nat Prod 66: 1022-1037.

Pettit GR, MukKu VJRV, CragG G, Herald DL, Knight JC, HERALD CL AND CHAPUIS JC. 2008. Antineoplastic agents. 558. Ampelocissus sp. Cancer cell growth inhibitory constituents. J Nat Prod 71: 130-133.

Pimenta LPS, NAscimento FC, Assunção ACS AND BOAVENTURA MAD. 2003. Acetogeninas de anonáceas isoladas de folhas de Rollinia laurifolia. Quím Nova 26: 319-322.

Pimenta LPS, NASCIMENTO FC, AsSunÇão ACS, Oliveira AB AND BOAVENTURA MAD. 2001. Laurifolin, a novel acetogenin from Rollinia laurifolia leaves. Tetrahedron Lett 42: 8433-8434.

Pimenta LPS, NAscimento FC AND BoAventura MAD. 2005. Acetogenins from the leaves of Rollinia laurifolia. Helv Chim Acta 88: 3225-3231.

RaYNAUd-LE Grandic S, FourneAu C, LAURENS A, Bories C, Hocquemiller R AND Loiseau PM. 2004. In vitro antileishmanial activity of acetogenins from Annonaceae. Biomed Pharmacother 58: 388-392.

ROMANHA AJ ET AL. 2010. In vitro and in vivo experimental models for drug screening and development for Chagas disease. Mem Inst Oswaldo Cruz 105: 233-238.

SAHAI MET AL. 1994. Annonaceous acetogenins from the seeds of Annona squamosa, adjacent bis-tetrahydrofuranic acetogenins. Chem Pharm Bull 42: 1163-1174.

SAntos LAR, BoAventura MAD AND Pimenta LPS. 2006. Cornifolin, a new bis-tetrahydrofuran annonaceous acetogenin from Annona cornifolia. Biochem Syst Ecol 34: $78-82$.
SANTOs LAR, BoAventura MAD AND PIMENTA LPS. 2007. Acetogeninas de anonáceas bioativas isoladas das sementes de Annona cornifolia A. St. -Hil. Rev Bras Plantas Med 9: 48-51.

SAntos LP, BoAventura MAD AND Oliveira AB. 1994. Crassiflorina, uma acetogenina tetra-hidrofurânica citotóxica de Annona crassiflora (araticum). Quím Nova 17: 387-391.

SAnTos LP, BOAVENTURA MAD, Sun NJ, CASSADY JM AND OLIVEIRA AB. 1996. Araticulin, a new bis-tetrahydrofuran polyketide from Annona crassiflora seeds. Phytochemistry 42: 705-707.

Shikanai-Yasuda MA, Telles Filho FQ, Mendes RP, Colombo AL AND Moretti ML. 2006. Guideliness in paracoccidioidomycosis. Rev Soc Bras Med Trop 39: 297-310.

VILA-Nova NA, MORAIS SM, FALCÃo MJC, MACHAdO LKA, BEVILÁQuA CML, COSTA IRS, BRAsil NVGPS AND ANDRADE JÚNIOR HF. 2011. Leishmanicidal activity and cytotoxicity of compounds from two Annonaceae species cultivated in Northeastern Brazil. Rev Soc Bras Med Trop 44: 567-571.

Waechter AI, Hocquemiller R, LAurens A And CAVÉ A. 1995. Glaucanisin, a new acetogenin from Annona glauca. Nat Prod Lett 6: 133-138.

Waechter AI, Hocquemiller R, LAURens A AND CAVÉ A. 1997. Glaucanetin and 10-hydroxy-glaucanetin, two new acetogenins from Annona glauca. Nat Prod Lett 10: 205-212.

Waechter A, Yaluff G, Inchausti A, Rojas de Arias A, Hocquemiller R, CAVÉ A AND Fournet A. 1998. Leishmanicidal and trypanocidal activities of acetogenins isolated from Annona glauca. Phytother Res 12: 541-544.

YANG H, ZHANG N, Li X, CHEN J AND CAI B. 2009. Structureactivity relationships of diverse annonaceous acetogenins against human tumor cells. Bioorg Med Chem Lett 19: 2199-2202.

Ye Q, He K, Oberlies NH, Zeng L, Shi G, Evert D AND MCLAUGHLIN JL. 1996. Longimicins A-D: novel bioactive acetogenins from Asimina longifolia (Annonaceae) and structure-activity relationships of asimicin type of annonaceous acetogenins. J Med Chem 39: 1790-1796.

Zeng L, Ye Q, Oberlies NH, Shi G, Gu ZM, He K AND MCLAUGHLIN JL. 1996. Recent advances in annonaceous acetogenins. Nat Prod Rep 3: 275-306. 